\title{
Artikkeli
}

\section{Tilannetaju ja tahdikkuus oppilaiden yhteisöllisessä digitaalisessa työskentelyssä}

\begin{abstract}
Tässä artikkelissa käsitellään alakouluikäisten oppilaiden kokemuksia yhteisöllisestä digitaalisesta sisällöntuottamisesta osana kouluopetusta. Mobiiliteknologiaa hyödyntävät projektit on toteutettu eri luokilla kahdessa peräkkäisessä ikäryhmässä. Digitaalinen aika ja kulttuuri korostavat omaehtoista tuottamista sekä omaa ajattelua ja ilmaisua. Onkin hedelmällistä tarkastella, miten oppilaat työskentelevät digitaalisissa ympäristöissä ja millaisia piirteitä heidän kokemuksistaan nousee esiin erityisesti tilannetajun ja tahdikkuuden osalta. Tilannetajulla viitataan oppilaan tilanteessa olemiseen ja kykyyn tehdä tuotannollisia ratkaisuja, tahdikkuudella taas eri tekijöitä huomioonottavaan ja kunnioittavaan toimintaan. Laadullisen tutkimuksen aineistona ovat oppilaiden kirjoitelmat digitaalisista sisällöntuottamisen projekteista. Tutkimuksen sisällönanalyysi valaisee oppilaiden tilannetajun ja tahdikkuuden ilmenevän yhteisöllisyytenä ja yhteistoimintana, joustavuutena sekä neuvotteluna ja läsnäolona. Nämä näyttäytyvät erityisesti suhteessa toisiin oppijoihin, suhteessa tuotettavaan digitaaliseen sisältöön sekä sen tuottamiseen käytettävään teknologiaan. Tutkimukseen osallistuneet viides- ja kuudesluokkalaiset oppilaat haluavat opiskella koulussa pienryhmissä vapaa-ajalta tuttua mobiiliteknologiaa hyödyntäen. Oppilaiden omaehtoinen teknologian ja mobiililaitteiden käyttö yhteisöllisissä projekteissa mahdollistaa tilannetajun ja tahdikkuuden käytännön harjoittamisen.
\end{abstract}

AVAINSANAT: digitaalinen tuottaminen, mobiiliteknologia, tahdikkuus, tilannetaju, yhteisöllinen oppiminen

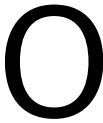
ppilaiden taidot mobiililaitteiden käyttäjinä sekä digitaalisen sisällön kuluttajina ja tuottajina tiedetään laajasti, mutta näitä taitoja hyödynnetään oppimisessa vielä vähän (ks. esim. OECD 2014). Teknologian käyttö koetaan haasteellisena, eikä sen tuominen luokkaan yksistään riitä toimintakulttuurin muutokseen, vaan tärkeässä roolissa ovat pedagogiset ratkaisut ja toimintamallit (Ryan \& Deci 
2000, 25, 54-67; Hellström ym. 2015, 52-61; Norrena 2013, 169-170 ja Sipilä 2013, 8 ). Pedagogisilla ratkaisuilla ja toimintamalleilla kehitetään uuden ajan oppimaisemaa, jota Suomessa on pohjustettu jo vuosia tuomalla viestintä- ja mediateknologiaa kouluarkeen (ks. esim. Vahtivuori-Hänninen \& Kynäslahti 2012, 243-245). Uusi perusopetuksen opetussuunnitelma (POPS 2014) tukee myös digitalisoituvaa oppimaisemaa sekä tulevaisuuden kannalta keskeisten taitojen kehittämistä.

Tutkimuksista ilmenee, että nuorten vapaa-ajalla tapahtuva omaehtoinen digitaalinen sisällöntuottaminen on osalle nuorista luovuuden ja oman ajattelun esittämisen kanava (Ito ym. 2010, 243-245; Kupiainen \& Sintonen 2009, 13-17). Kuitenkin koulukontekstiin sijoitettuna media ja teknologia liitetään tyypillisesti oppilaan kehittyviin tiedonhankintataitoihin sekä median ja teknologian hallintataitoihin (Opetushallitus 2011, 10; OECD 2014), mutta ei mahdollisuuteen oppia ja harjoitella yhteistyö- ja vuorovaikutustaitoja tai mahdollisuuteen tuottaa yhdessä sisältöä.

Tässä artikkelissa paneudutaan viides- ja kuudesluokkalaisten oppilaiden $(\mathrm{N}=48)$ kokemuksiin digitaalisissa sisällöntuottamisen projekteissa. Yhteisöllisellä digitaalisella työskentelyllä viittaamme oppilaiden pienryhmissä yhteistoiminnallisesti suunnittelemiin, toteuttamiin ja arvioimiin monimediaisiin projekteihin, joiden oppimistavoitteet perustuvat opetussuunnitelmaan. Projekteissa on tavoitteena sisällön oppimisen lisäksi kehittää muun muassa oppilaiden monilukutaitoja. Oppilaiden kokemuksissa nousi esille useita tilannetajuun ja tahdikkuuteen liittyviä piirteitä heidän ollessaan vuorovaikutuksessa toistensa kanssa ja työskennellessään tieto-ja viestintäteknologian kanssa, joten kiinnostuimme tästä näkökulmasta. Lisäksi oppilaiden tilannetajua ja tahdikkuutta on tutkittu vähän verrattuna muun muassa opettajista tehtyyn tutkimukseen (mm. van Manen 1991; Määttä \& Uusautti 2012, 21-39). Tilannetaju ja tahdikkuus liittyvät tulevaisuuden taitojen hallintaan, millä tarkoitetaan osaamista, jota oppilaat tarvitsevat siirtyessään työelämään ja yhteiskunnan jäseniksi: muun muassa projekti- ja tiimityöskentely, ongelmanratkaisutaidot, tietoja viestintätekniikan käyttötaidot sekä oppimaan oppiminen (ks. POPS 2014, 20-24; Binkley ym. 2012, 18-20).

Opetussuunnitelman 2014 perusteissa (POPS 2014, 17) on asetettu paljon tavoitteita yhteisölliselle oppimiselle ja ryhmässä toimimiselle, jo oppimiskäsityksessä lähdetään siitä, että oppiminen tapahtuu vuorovaikutuksessa toisten oppilaiden, opettajien ja muiden aikuisten eri yhteisöjen ja oppimisympäristöjen kanssa. Oppilaat oppivat ratkaisemaan ongelmia ja reflektoimaan oppimistaan, kokemuksiaan ja tunteitaan itse ja yhdessä toisten kanssa (Hellström ym. 2015, 58-59; POPS 2014, 17). Jotta yhteisöllinen, yhteistoiminnallisesti toteutettu oppiminen neuvotteluineen, riskeineen ja ristiriitojen ratkaisuineen onnistuu, oppilailta edellytetään tilannetajua ja tahdikkuutta.

Luokissamme oppilaiden työskentelyssä keskiössä ovat itseohjautuva toiminnallisuus, luovuus, yhdessä tekeminen ja tuottaminen reflektoiden omaa toimintaansa (ks. esim. Dewey 1957; Enkenberg ym. 2014; Freinet 1987; Hakkarainen 2009; Montessori 1948). Teknologia on voimakkaasti mukana tekemisen, ajattelun ja vuorovaikutuksen tukijana ja mahdollistajana (Enkenberg emt.; Hakkarainen emt.). Voidaan 
puhua opetuksesta osallisuuden kulttuurissa, jolla käsitetään oppilaiden mahdollisuutta luoda, jakaa, muokata monimediaisia sisältöjä (Jenkings ym. 2009, 5-14; Kupiainen \& Sintonen 2009, 14). Luokkien työskentelytapa on toiminut myös opettajille välineenä kehittää omaa pedagogiikkaansa.

\section{Yhteisöllinen oppiminen ja digitaalinen sisällöntuotanto}

Tutkimuksemme pohjautuu sosiokulttuuriseen käsitykseen yhteisöllisestä oppimisesta, joka on tilanne, jossa kaksi tai useampi henkilö yhdessä oppii tai pyrkii oppimaan. Heillä on tällöin yhteinen tehtävä, ja he pyrkivät pääsemään tavoitteeseensa: yhteiseen ymmärryksen rakentamiseen vuorovaikutuksessa toistensa kanssa (Dillenbourg 1999, 2; Lave \& Wenger 1991; Vygotsky 1978). Oppimisen keskiössä ovat ryhmän jäsenten positiivinen riippuvuus toisistaan, yksilöllinen vastuu, osallistuva avoin vuorovaikutus, sosiaaliset taidot ja yhdessä tehty arviointi ja pohdinta (Johnson \& Johnson 2014, 417-430; Sahlberg \& Sharan 2002, 385-403). Yhteisöllisessä oppimisessa oppilaat yhdistävät tietonsa ja taitonsa ratkaistakseen haasteellisia tehtäviä yhdessä tuoden oman kompetenssinsa ryhmän käyttöön. Tästä hyötyvät etenkin vähemmän osaavat oppilaat. (Winne ym. 2010.)

Yksilön roolilla on vaikutusta ryhmän vuorovaikutuksen luonteeseen; esimerkiksi johtajaroolissa oleva voi toiminnallaan joko passivoida ryhmän muita jäseniä tai viedä ryhmää tavoitteen suuntaan (Pennington 2005, 24). Oppilaiden väliset luottamukselliset suhteet lisäävät ryhmään kuulumisen tunnetta. Tästä syntyvä luottamuksen ilmapiiri on merkittävää avoimelle keskustelulle ja kokeilevalle toiminnalle. Yhteinen ajatus voittamisesta tai häviämisestä ryhmänä vahvistaa halua olla ryhmän jäsenenä (Johnson \& Johnson 2009, 368-369). Yhteisöllistä oppimista ja ryhmän tavoitteiden saavuttamista edistää ryhmän taito suunnitella ja organisoida työskentelyä, valita työskentelymenetelmiä sekä taito hyödyntää tarkoituksenmukaisia välineitä päästäkseen päämääräänsä (Arrow ym. 2000). Häkkinen ja Arvaja $(1999,210)$ korostavat, että oppimistehtävässä on oltava tilaa ristiriidoille ja väärinymmärryksille, jotta yhteisöllisen oppimisen kannalta merkittäviä neuvottelutilanteita syntyy.

Yhteisöllisestä oppimisesta ja digitaalisesta sisällöntuotannosta on puhuttu jo vuosia, mutta suomalainen koulu on suhteessaan digitaaliseen teknologiaan hieman konservatiivinen (Ilomäki \& Lakkala 2011, 12). Esimerkiksi Scardamalian ja Bereiterin (2008) mukaan tieto- ja viestintäteknologiaa tulisi käyttää enemmän tuottamiseen ja luovaan työskentelyyn, kuten tutkimuksessa mukana olevissa luokissa tapahtuu. Digitaalisella sisällöntuottamisella viitataan tässä artikkelissa teknologian avulla tuotettuihin ja esitettyihin tuotoksiin, kuten digitaaliset tarinat, verkkolehdet sekä virtuaalisessa pelimaailmassa tehdyt rakennelmat, jotka voivat itsessään olla välineitä sosiaaliseen vuorovaikutukseen (Berge 2006, 7; Sipilä 2013, 25-28). Teknologian hyödyntäminen oppimisprosessissa ei välttämättä johda oppilaiden yksin jäämiseen teknologian äärelle ja eristäytymiseen toisista vaan voi 
parhaimmillaan tehostaa yhteistoiminnallista oppimista (Johnson \& Johnson 2014). Opetussuunnitelman mukaisesti oppilaasta tulee aktiivinen toimija ja opettajasta työskentelyn ohjaaja, mahdollistaja ja vauhdittaja (POPS 2014, 17). Käynnissä oleva muutos oppilaiden teknologian kuluttajasta tiedon tuottajaksi ja luojaksi (Hellström ym. 2015, 87; Kotilainen 2011, 159-162; Schwartz 2015) on jo oppimisen arkea luokissamme.

Mobiiliteknologialla tarkoitetaan tässä artikkelissa helppokäyttöistä, mukana kuljetettavaa, pieninäyttöistä ja henkilökohtaisen kokemuksen antavaa laitetta (Henderson \& Yeow 2012, 78-79). Se mahdollistaa oppimisprosessissa rajattoman oppimaiseman, millä tarkoitetaan tässä tutkimuksessa oppimisen riippumattomuutta paikasta, ajasta ja tilanteesta lisäten oppilaan toimijuutta (Kurttila \& Lang 2013, 99-100; Sharples ym. 2005, 8). Tässä tutkimuksessa teknologian merkitys on laajempi kuin viestinnän tukeminen, sillä digitaalisissa sisällöntuottamisen projekteissa mobiililaitteilla mahdollistetaan tiedon välittäminen, muokkaaminen, rakentaminen ja uuden luominen. Useat tutkijat liittävät mobiiliteknologian käytön sosiokulttuuriseen teoriaan ja korostavat sen hyötyjä aitojen tilanteiden, yhteistoiminnallisuuden ja yksilöitävyyden näkökulmasta (mm. Kearney ym. 2012; Kotilainen 2011, 159-162 ). Henkilökohtainen mobiililaite antaa hyvät mahdollisuudet sitoutua ja motivoitua oppimisesta (Tanti \& Cameron 2011; Song 2014, 59-60). Tutkittujen luokkien oppilaat saattoivat vapaasti käyttää omia mobiililaitteitaan sekä koulun laitteita ja ohjelmia.

\section{Tilannetaju, tahdikkuus ja monilukutaito yhteisöllisessä tuottamisessa}

Tilannetaju ja tahdikkuus ovat usein ryhmän toiminnassa ja yhteisöllisyydessä keskeisiä ilmiöitä, mutta niihin ei kiinnitetä juurikaan huomiota kouluopetuksessa. Käsityksemme mukaan tahdikkuus ja tilannetaju kulkevat käsi kädessä. Niitä ei voi kuitenkaan suoraan rinnastaa samaksi käsitteeksi, vaikka tilannetajua ja tahdikkuutta käytetään arkikielessä lähes synonyymeina. Oppilaalla voi olla hyvä tilannetaju, mutta hänellä ei ole taitoa tai halua toimia tahdikkaasti (Salmivalli, 1999, 13-34). Tahdikkuus taas vaatii tilannetajua ja tahtoa toimia tilanteessa kunnioittavasti. Tahdikkuutta ja tilannetajua kehitetään parhaiten erilaisissa vuorovaikutustilanteissa, jotka edellyttävät sosiaalisia taitoja ja tunteiden kohtaamista.

Tilannetaju voidaan nähdä kykynä tulkita tilannetta ja reagoida tähän tulkintaan työskentelyä edistävästi. Se on ikään kuin käytännön järkeä, osin intuitiivistakin kykyä lukea toisia ihmisiä ja heidän tunnetilojaan (Chia \& MacKay 2007; Selman 1980; Zurita \& Nussbaum 2006; 292-293). Tilannetaju liitetään tutkimuksissa muun muassa johtamiseen ja koulumaailmassa opettajan johtajuuteen ja työrauhaan ( $\mathrm{mm}$. Belt 2013). Gregoryn ja Willisin (2013, 49-51) mukaan johtajalta edellytetään tilannetajua, joka näkyy johtajan osaamisena sopeutua tilanteeseen muuttamalla joko itseään tai vallitsevia olosuhteita tai kykynä poistua tilanteesta muualle, jossa olosuhteet ovat suotuisammat. 
Tahdikkuudella tarkoitetaan toiset huomioon ottavaa, joustavaa ja sulavaa toimintaa. Siihen liittyy olennaisesti ryhmän vahvistuminen ja yhteenkuuluvaisuuden tunne. (Naukkarinen 2011, 316-317.) Van Manenin $(1991,187)$ määritelmän mukaan opettajan pedagoginen tahdikkuus tarkoittaa kykyä löytää kasvatus- ja opetustilanteissa nopeasti tarkoituksenmukainen toimintatapa, joka on vastuullinen, luottamusta herättävä ja oivaltava. Samoja tilannetajun ja tahdikkuuden piirteitä liitetään tässä tutkimuksessa oppilaiden yhteisölliseen digitaaliseen työskentelyyn (ts. oppilaiden mediatuottamiseen), jota voidaan luonnehtia moninaiseksi kommunikatiiviseksi merkitystenannon prosessiksi (Burn \& Durran 2007, 19-21). Tässä tutkimuksessa kommunikatiivinen merkityksenanto on perusta oppilaiden monilukutaidon kehittämiselle.

Peruskoulun opetussuunnitelman perusteiden (POPS 2014, 22-23) mukaan monilukutaidolla tarkoitetaan erilaisten tekstien tulkitsemisen, tuottamisen ja arvottamisen taitoja, jotka auttavat oppilaita ymmärtämään monimuotoisia kulttuurisia viestinnän muotoja, sekä rakentamaan omaa identiteettiään. Se sisältää laaja-alaisen käsityksen tekstistä, jolla tarkoitetaan tässä sanallisten, kuvallisten, auditiivisten, numeeristen ja kinesteettisten symbolijärjestelmien avulla ilmaistua tietoa. Tekstiä voidaan tulkita ja tuottaa esimerkiksi kirjoitetussa, puhutussa, painetussa, audiovisuaalisessa tai digitaalisessa muodossa. Tulkintamme mukaan monilukutaidossa tilannetaju ja tahdikkuus tulevat esille oppilaiden projekteissa ja niiden tuotoksissa esimerkiksi tietoisuutena siitä, mitä, miten ja millaista tekstiä voidaan julkaista ja jakaa. Opetussuunnitelman määritelmässä korostuu (media)tekstien tulkitsemisen ja tuottamisen näkökulma, mutta monilukutaito ankkuroituu kielen ja kulttuurin suhteeseen (Hartikainen \& Harmanen 2015). Monilukutaidon voi kuitenkin käsittää myös laajana kulttuurisena ja intertekstuaalisena ilmiönä, jonka juuret ovat sekä globalisaatiossa, teknologisoitumisessa ja digitalisaatiossa. ${ }^{1}$

\section{Tutkimuksen lähtökohdat ja sen toteuttaminen}

Artikkeli perustuu tutkimukseen, jossa tarkastellaan viides- ja kuudesluokkalaisten oppilaiden kokemuksia luokissa toteutetuista yhteisöllisistä, digitaalisista sisällöntuottamisen projekteista, sekä erityisesti sitä, miten tilannetaju ja tahdikkuus ilmenevät oppilaiden kokemuksissa projektityöskentelystä suhteessa heidän keskinäiseen toimintaansa, digitaalisen tuottamisen prosessiin ja itse tuotettavaan sisältöön. Tutkimuskysymyksemme ovat: A) millaisena kokemuksena digitaalinen yhteisöllinen sisällöntuottaminen oppilaiden kirjoitelmissa ilmenee ja B) millaisia piirteitä tilannetajusta ja tahdikkuudesta niissä nousee esiin? Lisäksi pohdimme lopuksi, mitä uutta tällainen opiskelutapa sekä tilannetajun ja tahdikkuuden tarkastelu antavat sekä uudesta opetussuunnitelmasta että tulevaisuuden taidoista ja digitalisoituvasta koulusta käytävään keskusteluun.

Tähän laadulliseen tutkimukseen osallistui kaksi itäsuomalaisen yhtenäiskoulun luokkaa. Aineisto (taulukko 1) on kerätty keväällä 2015 ja se perustuu vuosina 2013- 
2015 toteutettuihin yhteisöllisiin digitaalisiin oppimisprojekteihin oppilaiden ollessa 4.- 6. luokilla. Tutkittavat luokat ovat kaksi peräkkäistä ikäryhmää, ja tutkimus toteutetaan opettamissamme luokissa. Oppilaat ovat työskennelleet jo useamman vuoden ajan yhteisöllisesti hyödyntäen digitaalisia välineitä ja ympäristöjä samojen opettajien johdolla. Toiminta on vakiintunut luokkien työskentelykulttuuriin.

Oppimisprojektit lähtevät opetussuunnitelman tavoitteista (Taulukko 1), jotka avataan yhdessä oppilaiden kanssa. Opettajat määrittelevät perehtymisen kohteena olevan ilmiön, oppilaat suunnittelevat pienryhmissä tavoitteiden mukaisesti oman oppimisprojektinsa. Suunnitelma toimii projektin käsikirjoituksena ja ohjaa työskentelyä. Työskentelyn aikana oppilaat hoitavat itsenäisesti kaiken projektiin liittyvän. Arviointia tehdään koko prosessin ajan, ja lopullinen oppimistuotosten esittäminen ja arviointi tehdään projektin päätteeksi. Arvioinnissa kiinnitetään huomiota ryhmän ja yksilöiden työskentelyyn sekä tiedollisten tavoitteiden saavuttamiseen. Arviointiin osallistuu oppilaiden ja opettajan lisäksi myös vanhempia. Tässä kokonaisessa oppimisprosessissa opettaja ohjaa oppilasryhmien tiedonhankinnassa, tavoitteidenmukaisessa työskentelyssä sekä mahdollistaa erilaisten fasiliteettien käytön. Lisäksi opettajan tärkeä tehtävä on vauhdittaa, kannustaa ja innostaa.

Aineiston ensimmäinen osa kerättiin kirjoitelmina viidennen luokan oppilaiden kokemuksista digitaalisen sisällöntuottamisen projekteista niiden päätyttyä ja toinen osa kuudennen luokan viimeisen projektin aikana oppimispäiväkirjoina keväällä 2015. Ilmiöpohjaiset, yli oppiainerajojen menevät oppimisprojektit, ovat kokonaisuutena tuottaneet monimediaista ja moniulotteista aineistoa, joista tätä artikkelia varten on rajattu aineisto (Taulukko 1). Tutkimusaineiston ensimmäisen osan kirjoitelmiin oppilaita ohjeistettiin pohtimaan vapaamuotoisesti omia kokemuksiaan erityisesti uusimmista projekteista: miten he toteuttivat projektit, millaisia ongelmia projekteissa oli ja miten ongelmat ratkaistiin, millaisia tunteita opiskelu herätti, miten huomioitiin erilaiset oppijat sekä mitä he oppivat projektin aikana itsestään ja ryhmästä. Toinen osa aineistosta on kerätty neljä viikkoa kestäneestä oppimisprojektista, jonka aikana oppilaat kirjoittivat henkilökohtaista oppimispäiväkirjaa jokaisen työskentelykerran jälkeen. Ohjeena oli kertoa mitä oli tehty, opittu ja ymmärretty, jäikö jotain epäselväksi sekä mistä tietoa ja taitoja haettiin ja miten opiskeltiin. Lisäksi oppilaita ohjeistettiin pohtimaan tuntemuksiaan omasta ja ryhmän toiminnasta. 
Taulukko 1. Ilmiöpohjaisten projektien ja niistä kerätyn aineiston kuvaus.

\begin{tabular}{|c|c|c|}
\hline & I osa & Il osa \\
\hline $\begin{array}{l}\text { Projektit, joihin } \\
\text { oppilaiden kokemukset } \\
\text { perustuvat, toteutus }\end{array}$ & $\begin{array}{l}\text { A) Enemmän samaa kuin } \\
\text { erilaista, joulukuu 2013- } \\
\text { joulukuu 2014, } \\
\text { 4.-5.Ik } \\
\text { http://bit.ly/1UBZp1X } \\
\text { B)Työtä tehdään, } \\
\text { syyskuu 2014-toukokuu 2015, } \\
\text { 5. Ik } \\
\text { http://bit.ly/1PNBgEw }\end{array}$ & $\begin{array}{l}\text { C) Suomen historiaa } \\
\text { 1500-1700-luvuilla } \\
\text { huhtikuu 2015, } \\
6.1 k \\
\text { http://bit.ly/1ZeVVZS }\end{array}$ \\
\hline $\begin{array}{l}\text { Projektiin sisältyvät } \\
\text { oppiaineet }\end{array}$ & $\begin{array}{l}\text { äidinkieli } \\
\text { kuvataide } \\
\text { ympäristö- ja luonnontieto } \\
\text { biologia } \\
\text { uskonto } \\
\text { englanti }\end{array}$ & $\begin{array}{l}\text { äidinkieli } \\
\text { historia } \\
\text { kuvataide } \\
\text { uskonto }\end{array}$ \\
\hline $\begin{array}{l}\text { Eheyttäminen ja } \\
\text { aihekokonaisuudet (OPS } \\
\text { 2004) }\end{array}$ & $\begin{array}{l}\text { Ihmisenä kasvaminen } \\
\text { Kulttuuri, identiteetti ja } \\
\text { kansainvälisyys } \\
\text { Viestintä- ja mediataito } \\
\text { Osallistuva kansalaisuus ja } \\
\text { yrittäjyys } \\
\text { Ihminen ja teknologia }\end{array}$ & $\begin{array}{l}\text { Kulttuuri, identiteetti ja } \\
\text { kansainvälisyys } \\
\text { Viestintä- ja mediataito } \\
\text { Osallistuva kansalaisuus ja } \\
\text { yrittäjyys }\end{array}$ \\
\hline $\begin{array}{l}\text { Projekteissa käytössä } \\
\text { olleet digitaaliset } \\
\text { välineet }\end{array}$ & $\begin{array}{l}\text { Tablet-laitteet ( } 6 \mathrm{kpl} \text { yhteisesti } \\
\text { luokan käytössä), digikamerat, } \\
\text { oppilaiden omat laitteet } \\
\text { (puhelimet, tabletit, kamerat, } \\
\text { tietokoneet) }\end{array}$ & $\begin{array}{l}\text { Henkilökohtaiset tablet-laitteet } \\
\text { ( } 25 \mathrm{kpl}) \text {, oppilaiden omat laitteet } \\
\text { (puhelimet, tabletit, kamerat, } \\
\text { tietokoneet) }\end{array}$ \\
\hline $\begin{array}{l}\text { Projekteissa käytössä } \\
\text { olleet ohjelmistot ja } \\
\text { digitaaliset ympäristöt }\end{array}$ & \multicolumn{2}{|c|}{$\begin{array}{l}\text { Oppilaiden valitsemat ohjelmistot ja jakoympäristöt } \\
\text { esim. editointiohjelmat, piirto-ohjelmat, kuvankäsittelyohjelmat, } \\
\text { Youtube, Google-ympäristö, WhatsApp }\end{array}$} \\
\hline $\begin{array}{l}\text { Tutkimusaineisto } \\
\text { (oppilaiden reflektiot) }\end{array}$ & $\begin{array}{l}\text { 5. luokka, toukokuu } 2015 \\
\text { kirjoitelmat }(\mathrm{N}=23)\end{array}$ & $\begin{array}{l}\text { 6. luokka, huhtikuu - toukokuu } \\
2015 \\
\text { oppimispäiväkirjat }(\mathrm{N}=25)\end{array}$ \\
\hline Liuskat (A4) & 23 & 120 \\
\hline
\end{tabular}

\section{Aineiston analyysi}

Tutkimusaineistolle tehtiin teemoittelu ja sisällönanalyysi, joilla tavoiteltiin ilmiön kuvausta yleisessä ja tiivistetyssä muodossa, kuitenkaan kadottamatta kaikkia niitä nyansseja, joita tutkittavaan ilmiöön liittyy (Tuomi \& Sarajärvi 2002, 105, 110). Tarkastelimme aluksi, miten yhteisöllinen toiminta digitaalisessa sisällöntuotannossa ilmenee oppilaiden kokemuksista sekä poimimme kirjoitelmista ja oppimispäiväkirjoista 
digitaalisuuteen viittaavia ilmauksia, joista muodostettiin suurempia kokonaisuuksia eli teemoja. Sisällönanalyysin pohjalta aineistoa ja teoriaa rinnakkain tarkastellen hahmottelimme pääluokat tilannetajun ja tahdikkuuden ilmenemismuodoille: a) yhteisöllisyys ja yhteistoiminta, b) joustavuus sekä c) neuvottelu ja läsnäolo. Näiden pääluokkien ohjaamina jaottelimme oppilaiden kokemukset teemoittain (Eskola \& Suoranta 2014, 150-160).

Luotettavuuden osalta voidaan pohtia, ovatko oppilaat kirjoittaneet kokemuksistaan kattavasti. Tätä pyrimme parantamaan aineistotriangulaation avulla, tarkastusaineistona olevilla videohaastatteluilla. Kuudennen luokan oppilaiden oppimispäiväkirjat, joissa heitä pyydettiin kuvaamaan kokemuksiaan, ovat olleet osa heidän äidinkielen arviointiaan. Aineistoa on käsitelty anonyymisti ja sitaateissa esiintyvät nimet on muutettu. Tutkijat ovat perehtyneet toistensa tutkimusaineistoihin luotettavuuden lisäämiseksi eli aineistoja on myös analysoitu ristiin. Tiedostamme oman lähtökohtamme ja roolimme tutkittavina olevien luokkien opettajina (kaksi artikkelin kirjoittajista) ja siksi olemmekin pyrkineet reflektoimaan myös toisiamme kriittisesti (Ahonen 1994, 122; Koro-Ljungberg 2005, 281). Kirjallisuuteen tutustuminen ja yhteiset keskustelut tutkimusaiheesta ovat auttaneet myös tulkintojen syventämisessä ja esiymmärryksen tiedostamisessa (Moilanen \& Räihä 2010, 52-53).

\section{Tulokset: Yhteisöllinen toiminta digitaalisessa sisällöntuotannossa sekä tilannetaju ja tahdikkuus oppilaiden kokemuksissa}

Tutkimusaineistoa on tarkasteltu suhteessa oppilaiden yhteisölliseen toimintaan digitaalisessa sisällöntuotannossa sekä digitaalisen tuottamisen prosessina. Tavoitteena ei ole yleistettävä kuvaus, vaan ymmärryksen lisääminen. Digitaalisessa tuottamisessa ilmenee oma-aloitteisuutta, monipuolista laitteiden ja ohjelmistojen käyttöä sekä valmiutta toimia tilanteen mukaisesti. Tilannetaju ja tahdikkuus näyttäytyvät sekä yhteisöllisessä digitaalisessa toiminnassa että yhteisöllisyyteen ja yhteistoimintaan, joustavuuteen sekä neuvotteluun ja läsnäoloon liittyvinä seikkoina. (Kuvio 1.) 
Kuvio 1. Yhteenveto oppilaiden kokemuksista tilannetajun ja tahdikkuuden näkökulmasta.

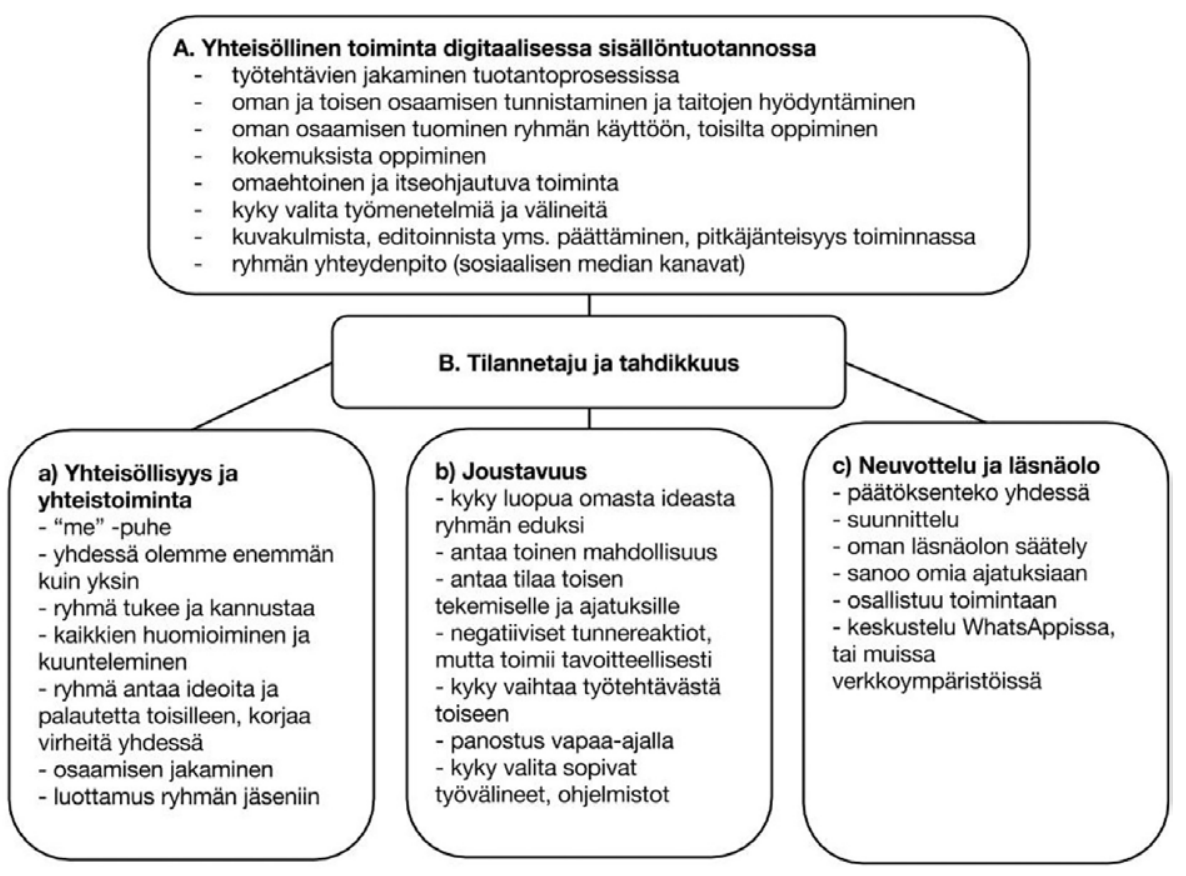

\section{Digitaalinen sisällöntuotanto pienryhmässä}

Aineistosta nousevat oppilaiden kokemukset liittyvät digitaaliseen sisällöntuotantoon yhteisöllisenä puheena (me-puheena) ja toiminnan kuvauksena, jossa ilmenevät erilaiset roolit projektissa, uuden oppiminen, oma digiosaaminen ja sen jakaminen, mobiilivälineiden ja ohjelmien hyödyntäminen pitkäjänteisessä prosessissa sekä ryhmän yhteydenpitotavat sosiaalisessa mediassa:

Mietimme pitkään, kuka kuvaa ja kuka haastattelee. Päädyimme yhteisymmärrykseen kun mietimme, kenellä on eniten kuvaus kokemusta. (Oppilas 5.lk, E33).

Tuotantoprosessin aikana oppilas saattaa vaihtaa roolia luontevasti tilanteesta toiseen sen vaatimalla tavalla tai kiinnostuksen ohjaamana, lisäksi hänellä voi olla päällekkäisiä rooleja. Tehtävien jakautumisessa oppilaat näyttävät hyödyntävän toistensa erilaista osaamista päästäkseen ryhmän haluamaan tulokseen.

Huomattavaa on, että osa oppilaista näyttää käyttävän vapaa-aikaansa uusien, projektin kannalta hyödyllisten ohjelmien opetteluun ja he hyödyntävät taitojaan pienryhmän hyväksi. Aineistosta käy myös ilmi, että muutamat oppilaat osaavat yhdistää useita ohjelmia erilaisten efektien ja visuaalisuuden aikaansaamiseksi. Oppilaiden 
tilannetaju ja kyky soveltaa ilmenee digitaalisena osaamisena ja ohjelmien tuntemuksena mahdollistaen omien tuotosten tekemisen heille ominaisella ja sujuvalla tavalla.

Vaikka oppilaat innostuvat herkästi mobiililaitteista oppimistarkoituksissa, kaikki oppilaat eivät luonnostaan ole taitavia mobiililaitteiden ja teknologiavälineiden käyttäjiä. Oppiminen tapahtuu usein kaverin ohjaamana (ks. Winne ym. 2010) tai Youtubevideoiden avulla-näin tässäkin tutkimuksessa:

Tiina [toisesta ryhmästä] tuli myös opettamaan meille miten sitä ohjelmaa käytetään jossa voi tehdä videota minecraftistä. (Oppilas, 6.lk, 023).

Vaikka oppilaat ovat valmiita opettelemaan uusia taitoja, he usein valitsevat ja vaihtavat itselleen mielekkäimmän ja helpoimman työtavan, välineen tai ohjelman: "Tein Matin kanssa suunnitelmaa paperille, kolmiulotteisesta ylivertaisesta koulusta. Se oli vaikea tehtävä ja vaihdoimme työskentelyn paperilta Minecraftiin. Tehtävä alkoi luonnistua siellä." (Oppilas, 6.Ik, O20). Aineiston valossa vaikuttaa siltä, että viides- ja kuudesluokkalaiset oppilaat ymmärtävät selkeästi mahdollisuutensa vaikuttaa digitaalisen tuotoksen sisältöön, ulkoasuun ja lopulliseen muotoon. Tämä ilmenee heidän sitkeänä "jouduimme ottamaan pätkän monta kertaa uudestaan ja uudestaan" -työskentelynä. Oppilailla on voimakas tarve tehdä lopputuotoksesta omannäköinen ja "hyvä", henkilökohtainen ja ryhmän taidonnäyte. Tämä ilmenee usealla lopputuotoksen laadukkuuteen liittyvällä kommentoinnilla: "näyttäisi aidolle", "tykkään editoinnista paljon... sai itse päättää minkälaisen tuloksen haluaa", "...mitä maassa voisi muuttaa niin, että se olisi parempi..".

Erään oppilaan kokemuksessa uuden oppiminen tapahtuu epäonnistumisten kautta:

Kamera jolla Pekka kuvasi teki sillä tavalla, että kun painoi "kuvaa"- nappulaa, niin kamera odotti noin 4-5 sekuntia ja rupesi vasta sitten kuvaamaan. Pekka huomasi tämän vasta myöhemmin ja minun mielestäni melkein kaikki klipit olivat huonoja. (Oppilas 6.lk, O19).

Kuvanlaadun selvittyä ryhmä kuvasi otokset sitkeästi uudestaan. Epäonnistumiset ja virheet kuuluvat luonnollisesti digitaaliseen tuottamiseen, mutta digitaalisuuden etu on juuri mahdollisuudessa helposti ja nopeasti korjata tilanteet tai valita toisin. Vaikuttaa siltä, että tähän tutkimukseen liittyvissä projekteissa digiteknologian käyttö kasvatti oppilaita omalta osaltaan pettymysten ja epävarmuuden sietoon:

"...ongelmia vähän haastattelun kuvaamisessa, koska ipadistä loppui tila kesken ja ääni ei oikein kuulunut. Joten jouduin ottamaan haastattelun melkein uudestaan ja se ärsytti minua vähän." (Oppilas 5.lk, E37).

Erilaisilla laitteilla työskennellessään oppilaat näyttävät pystyvän itsenäisesti ja joustavasti muuttamaan suunnitelmiaan ongelmien ilmaantuessa ja jatkamaan eteen- 
päin tuottavasti ilman opettajan apua tai ohjeita. Aineiston valossa voidaan todeta, oppilaiden ennakkoluuloton asenne ja innostunut uteliaisuus kannustaa kokeilukulttuuriin ja tukee ongelmanratkaisutaitojen kehittymistä (Norrena 2013, 169-170; Prensky 2012, 186-189). Oma-aloitteisuudesta kertoo esimerkki, jossa oppilas otti itse yhteyttä kansainväliseen ohjelmistoyritykseen, joka vastasi oppilaan pyyntöön antamalla hänen käyttöönsä tarvittavan pilvitallennustilan ja editointiohjelman. Tämä oli oppilaalle hyvä kokemus oman toiminnan merkityksestä ja yrittäjyydestä uuden opetussuunnitelman perusteiden hengessä (ks. POPS 2014, 22-24).

Oppilaat näyttävät osaavan ottaa huomioon sisällön ja katsojan asettamat vaatimukset. He valitsevat tilannetajuisesti ja tahdikkaasti esimerkiksi tuottamaansa sisältöön sopivan kielenkäytön, esiintymistavan tai julkaisukanavan pienryhmätuotokselleen:

Aina kun julkaisimme videon YouTubeen, se laitettiin meidän yksityiselle käyttäjälle koska dokumenteissamme lelokuvissamme käytettiin usein kuvia joita ei saa julkaista. (Oppilas, 5.Ik, E29).

Oppilaiden kertoman mukaan yhteisöllinen työskentely digitaalisesti etenee kasvokkain tapahtuvan vuorovaikutuksen lisäksi sosiaalisen median välityksellä monella eri tasolla ja eri aikoina:

Juttelimme wapissa [oppilaiden itse perustamassa, koulun ulkopuolisessa WhatsApp-ryhmässä] ja Sanna kertoi, että leffa on valmis ja kestää alle 2 minuuttia. (Oppilas 6.Ik, O19).

Keskustelut kerrottiin myös niille oppilaille, jotka eivät itse olleet WhatsApp-ryhmässä. Tämä kuvastaa oppilaiden tahdikasta käyttäytymistä kaikkia ryhmän jäseniä kohtaan.

\section{Yhteisöllisyys ja yhteistoiminta}

Yhteisöllisyys nousee esiin voimakkaasti kaikkien oppilaiden kirjoitelmissa "me"puheena, toisten tukemisena ja yhteisenä tekemisenä. Yhdessä työskennellessä omat ideat kehittyvät uudelle tasolle ja ryhmän yhteistyö auttaa ongelmien ratkaisemisessa. Oppilaat pyrkivät työskentelemään yhteisen tavoitteen saavuttamiseksi joustavasti ja sulavasti vuorovaikutuksessa toistensa kanssa (ks. Dillenbourg 1999, Naukkarinen 2011). Tahdikkuus näyttäytyy lisäksi oppilaiden puheena virheistä. Yhdessä tehdyissä oppimistuotoksissa olevista virheistä puhutaan tuotoksen; "lehden kirjoitusvirheitä", ei yksittäisen oppilaan tekeminä virheinä.

Oppilaiden kokemuksissa luottamuksen ja ilmapiirin rakentamiseen sovelletaan tilannetajua ja tahdikkuutta, jotta koko ryhmän kompetenssi saadaan käyttöön:

Hiljaiset täytyy ottaa ahkerasti mukaan projektiin, jotta se on heistäkin hauskaa, vaikka he eivät välttämättä puhuisi paljoa. (Oppilas, 5.lk, E26). 
Avoin oppimisympäristö luo tilaa myös ristiriidoille ja erimielisyyksille. Oppilaiden puheesta näkyy mahdollisuus yhteisöllisen oppimisen kannalta merkittäviin tilanteisiin (vrt. Häkkinen \& Arvaja 1999). Ristiriidat eivät estä työskentelyä, vaan oppilaat ovat pääasiassa selvittäneet ongelmat keskenään:

Seuraavalla tunnilla onneksi sovimme riidat, mutta sitä ennen oli todella pitkä pala-

veri. Palaverissa sovimme asiat, mutta kaikkia ei oikein kiinnostanut olla juuri siinä ryhmässä, joten ryhmiä piti vaihtaa. Onneksi pääsimme kuitenkin yhteisymmärrykseen eikä kenellekkään jäänyt paha mieli. (Oppilas, 6.lk, 04).

Yksittäisten oppilaiden toiminta ilmenee toisten kommenteissa häiritsevänä ja epämiellyttävänä asiana, kuten liiallinen johtajarooli tai keskittyminen muuhun kuin työskentelyyn. Tällaiseen "johtajana oloon!!" ei juuri kiinnitetä huomiota toiminnan tasolla, vaikka tilanne osittain passivoi ryhmän muita jäseniä (ks. Pennington 2005). Toisaalta vaikuttaa siltä, että ryhmän sitoutuminen projektiin palauttaa toiseen asiaan keskittyneen oppilaan työskentelyn pariin:

Jouduimme ottamaan kohtauksia monta kertaa uudestaan, joten alussa siitä ei tullut mitään. Kun me ryhdistäydyttiin ja saatiin projekti tehtyä... Projekti pitää joka tapauksessa tehtyä määräpäivään mennessä. (Oppilas, 5.lk, E33)

\section{Joustavuus}

Joustavuus ilmenee oppilaiden kykynä luopua omista näkemyksistään ryhmän yhteisen päämäärään saavuttamiseksi. He ovat oivaltaneet, että kuuntelemalla avoimesti toistensa erilaisia ajatuksia voi oppia uusia näkökulmia asioista:

Itse en pitänyt oikein niistä aseen otto kohtauksista, itse asiassa vihasin niitä, mutta ajattelin kuitenkin, että näin isossa ryhmässä on pakko joustaa aika paljon (loppukommentti niistä aseen otto jutuista tuli tosi hienot :)) (Oppilas, 6.lk, 07).

Kielteiset tunnereaktiot ilmenevät oppilaiden puheessa suuttumisena, ärsyyntymisenä ja hermostumisena toisten toimintaan tai yhdessä tehtyihin ratkaisuihin. Toisten ryhmäläisten huomioimisen lisäksi tilannetaju näyttäytyy myös joustavuutena tilanteissa, joissa oppilaiden täytyy muuttaa itsenäisesti ja nopeasti työsuunnitelmiaan, välineitään tai toimintaansa tarkoituksenmukaisesti (ks. Van Manen 1991; Arrow ym. 2000). Lisäksi ryhmän jäsenillä on valmiutta joustavasti käyttää yhteistä vapaaaikaansa projektiin, kuten eräs pienryhmä, joka teki yhteisen langattoman verkon vaatimaa Minecraft-projektia koulupäivän jälkeen. 
Neuvottelu ja läsnäolo

Erilaisia neuvottelu- ja ratkaisukeinoja ovat keskustelut, äänestykset, arvonnat, kompromissit sekä pelien avulla voittajan valinnat:

Meillä oli ongelmia päättää kuka kuvaa ja kuka haastattelee, mutta ratkaisimme ongelmat miettimällä kuka on muissa projekteissa kuvannut eniten, ja jaoimme kaiken sovussa. (Oppilas, 5.lk, E35).

Oppilaat ovat sisäistäneet suunnittelun yhdeksi tärkeäksi työvaiheeksi ja ymmärtäneet sen haasteellisuuden. Eräs oppilas kuvaa yhdessä tehtyä suunnittelutyötä paremmin onnistuneeksi kuin yksin tehtynä. Neuvotteluissa käy myös ilmi oppilaiden erilainen harjaantuneisuus sosiaalisissa vuorovaikutustaidoissa. Toinen oppilas kertoo tunnistavansa omat tunteensa ja pyrkii ennakoimalla välttämään kielteisiä reaktioita. Hän pyrkii tietoisesti säätelemään omaa läsnäoloaan. Myöhemmin hän toteaa, että läsnäolon säätely ei onnistunut, koska toiset eivät ole toimineet oppilaan ennakkooletusten mukaisesti. Ryhmän muiden oppilaiden kommenteissa kyseisen oppilaan toiminta hetkittäin näyttäytyy ärsyttävänä ja ryhmän aitoa vuorovaikutusta häiritsevänä toimintana, mutta se ei estä työskentelyä (ks. Pennington 2005) Oppilaiden läsnäolo ryhmässä ilmenee myös haluna auttaa toisia:"koittanut antaa hyviä neuvoja", pyytää apua, osallistua aktiivisesti ryhmän toimintaan,"tehdä mahdollisimman paljon töitä" ja tuoda omat ajatuksensa esille. Vastaavasti myös ryhmän jäseniltä odotetaan aktiivista läsnäoloa ja tasapuolista työskentelyä yhteisen tavoitteen saavuttamiseksi.

\section{Digitaalinen työskentely harjaannuttaa tilannetajua ja tahdikkuutta}

Yhteisöllinen sisällöntuotanto tekee oppilaiden toiminnasta ja oppimisesta läpinäkyvää, toiminnallista, aktiivista ja innostavaa. Oppilasryhmän digitaalinen tuotos kertoo oppilaiden tavasta käsitellä tutkittavaa ilmiötä ja antaa heille mahdollisuuden käyttää erilaisia ilmaisumuotoja ja tuoda näkyväksi omaa ajatteluaan ja kiinnostuksen kohteitaan. Teknologia antaa monipuoliset mahdollisuudet avartaa näkökulmia, tiedonrakentamisen ja esittämisen tapoja, yhteistoiminnan muotoja, yhteisöllistä tekemistä sekä vuorovaikutusta. Kuten aikaisemmin totesimme oppilaat pystyvät työstämään projektejaan ajasta ja paikasta riippumatta. Oppimistuotosten julkaisu vaatii oppilailta tilannetajua valitun median ja tuotoksen tekstityypin suhteen, heidän tulee miettiä mitä, miten ja milloin he voivat julkaista sekä kommentoida.

Tutkimukseen osallistuneet viides- ja kuudesluokkalaiset oppilaat haluavat työskennellä ja opiskella koulussa pienryhmissä vapaa-ajalta tuttua mobiiliteknologiaa hyödyntäen. Oppilaiden omaehtoinen teknologian ja mobiililaitteiden käyttö edistää vuorovaikutusta mahdollistaen jatkuvan kommunikoinnin, muokkaamisen, jakamisen ja keskinäisen reflektoinnin. Oppilaan tahdikkuus ilmenee kykynä ottaa toiset huomioon ja kohdata heidät vastuuntuntoisella, kunnioittavalla ja empaattisella tavalla. 
Tutkimustuloksemme tukevat aiempien tutkimusten (mm. Sipilä 2013; Paavola ym. 2006) ajatuksia siitä, että kouluyhteisön tulisi muuttua yhteisöllisempään ja osallistavampaan suuntaan, jotta digitaalisuuden ja teknologian tuomat mahdollisuudet pystytään hyödyntämään monipuolisesti oppimisen ja vuorovaikutuksen tukemiseksi. 2010-luvun koulun ei ole mitään syytä jättäytyä digitaalisen teknologian ulkopuolelle.

Oppilaat kokevat digitaaliset projektit innostavina ja hauskoina samoin kuin opettavina, koska projektissa oppilaat pystyvät yhdessä miettimään ja pohtimaan asioita. He kokevat oppivansa toisiltaan ja saavansa uusia ideoita omaan ajatteluun. Yhdessä tekeminen on mielekästä, vaikka oppilaat joutuvat kohtaamaan ristiriitoja ja kokemaan negatiivisia tunteita työskentelyn aikana. Kuten aiemmissa tutkimuksissa on todettu (ks. Hakkarainen ym. 2013; Paavola ym. 2006; Taylor \& Parson 2011) oppilaat sitoutuvat pitkäjänteiseen työskentelyyn omannäköisen tuotoksen aikaansaamiseksi. Tutkimuksemme tukee Kristin Bassin ja Elizabeth Bandyn (2010,49) nuorten mediatuottamista koskevia tutkimustuloksia, joiden mukaan tuotoksien aikaansaaminen edellytti kehittymistä toisten kanssa työskentelyssä, yhteisöllistä ongelmien ratkaisua ja valintojen tekoa sekä toisten ideoiden ja näkemysten kunnioittamista ja arvostamista.

Vaikuttaa siltä, että helppokäyttöinen mobiiliteknologia kannustaa oppilaita työstämään ja muokkaamaan tuotoksiaan joustavasti. He sallivat ja sietävät virheitä ja oppivat niistä. Vapaus valita mobiiliväline ja työtapa näyttää kannustavan oppilaita oman osaamisen monipuoliseen soveltamiseen, omaan luovuuteen ja oman digitaalisen osaamisen esilletuomiseen ja jakamiseen. Opettaja voi vaikuttaa siihen, että rajattomat mahdollisuudet tuotoksen työstämiseen eivät johda liialliseen itsekriittisyyteen ja täydellisyyden tavoitteluun tai valheellisesti visuaalisuuden keinoin 'kevytsisältöiseen' ja pinnalliseen lopputuotokseen.

Tutkimuksemme liittyy oppilaiden yhteisölliseen sisällöntuottamiseen, joka on vielä valitettavan vähäistä opetuskäytössä kouluissa (ks. Ilomäki \& Lakkala 2011; Järvelä ym. 2011). Omaehtoinen digitaalinen osaaminen näyttää kasaantuvan joillekin oppilaille heidän innostuksensa ja mielenkiintonsa kannustamina tehden heistä asiantuntijoita, jotka omassa roolissaan 'läikyttävät' Thompsonin ja Hallin (2008) toteamalla tavalla vapaa-ajalla kertynyttä osaamistaan ryhmän muille jäsenille. Tulosten valossa osaamisen jakaminen tukee oppilaan myönteistä käsitystä itsestään ja roolia ryhmässä, sekä rikastuttaa ryhmän osaamista. Tämä puolestaan vaikuttaa ryhmän vuorovaikutukseen myönteisesti yhtenäistäen sitä.

Digitaalinen tuottaminen harjaannuttaa tämän tutkimuksen valossa oppilaiden roolia sekä tuottajana että kuluttajana. Vaikka vain osan nuorista tiedetään toimivan luovina sisällöntuottajina vapaa-ajallaan (esim. Ito ym. 2010; Kupiainen 2013), aineistomme antaa viitteitä, että sisällöntuottaminen lisääntyy oppilailla koulun mallin innoittamana. Pidämme tätä tutkimuksen yhtenä kiinnostavana havaintona. Koulun merkitys näiden taitojen kehittämisen paikkana on osalle oppilaista suuri, sillä kaikki eivät kehity näissä taidoissa ohjaamatta, kuten Bass ja Bandykin $(2010,49)$ toteavat.

Toinen tärkeä havainto on, että pienryhmässä toteutettu digitaalinen sisällöntuottaminen edellyttää ja vaatii oppilailta tilannetajua ja tahdikkuutta, jotka ilmenevät 
oppilaiden kokemuksissa yhteisöllisyytenä ja yhteistoimintana, joustavuutena sekä neuvotteluna ja läsnäolona. Yhteisöllisen oppimisen lisäksi oppimaiseman ja oppimistehtävän väljyys sekä mahdollisuus digiteknologian käyttöön (osin oppilaiden itse valitsemilla tavoilla ja laitteilla) antavat tilaa erimielisyyksille, joiden ratkominen ja yhteiseen käsitykseen pääseminen edellyttävät oppilailta tilannetajua ja tahdikkuutta (vrt. Häkkinen \& Arvaja 1999). Tulostemme mukaan tavoitteeseen pääseminen ja yhdessä tekeminen menevät ristiriitojen edelle. Oppilaat ovat valmiita joustamaan, neuvottelemaan ja toimimaan yhteistyössä, vaikka se olisi välillä haasteellista. Oppilaiden kokemusten perusteella yhteisölliseen mediatuottamiseen liittyy myös nopeita, tarkoituksenmukaisia ratkaisuja, jotka kertovat vastuullisuudesta ja oivaltavuudesta sekä 'omalla' teknologisella alueella toimimisesta, sekä siitä, että oppilaat ovat sisäistäneet ryhmän sosiaalisia sääntöjä (ks. van Manen 1991; Naukkarinen 2014). Oppilaiden keskinäinen luottamus toisiinsa tukee yhteistoimintaa. Toisaalta näyttää siltä, että joidenkin oppilaiden itsekeskeisyys voi vaikeuttaa luottamuksen syntymistä ryhmän jäsenten välillä.

Tutkimuksen pohjalta syntyneen kokonaiskuvan perusteella voimme päätellä, että oppilaiden toimintaa leimaa voimakas halu työskennellä yhdessä digitalisoituvassa oppimaisemassa, koska se on ennen kaikkea "mukavaa". Yhtenä jatkotutkimusaiheena nouseekin kysymys, millaista oppiminen digitalisoituvassa oppimaisemassa on: vaikuttaako esimerkiksi oppilaiden halu työskennellä toisten kanssa oppimisen laatuun? Oppilaat toimivat yhdessä tavoitteiden saavuttamiseksi, ja näin työskennellessä tuotoksista on mahdollista saada "parempia" (myös oppilaan omasta näkökulmasta) ja toisaalta tuotosten muokattavuus ja toistettavuus sekä oman esiintymisen näkeminen sitouttavat työskentelyyn. On myös pidettävä mielessä, että tutkimuskohteena olleet yhteisölliset digitaaliset oppimisprojektit edellyttävät opettajan paneutumista yhteisöllisen oppimisen lisäksi oppilaan itseohjautuvuutta ja osallisuutta tukevaan pedagogiikkaan.

Tutkimustuloksistamme voi löytää yhteneväisyyksiä keskeisiin tulevaisuuden taitoihin liittyen (ks. POPS 2014 20-24; Binkley ym. 2012, 18-20). Näkemyksemme mukaan yhteisöllisissä digitaalisissa oppimisprojekteissa tilannetajun ja tahdikkuuden merkitys on suuri, ja ne ovat osa sosiaalisia vuorovaikutustaitoja ja vastuuntuntoiseksi digitaalisen ajan kansalaiseksi kasvamista (vrt. Sintonen 2012, 73, 77), joita myös työelämässä arvostetaan. Ongelmien asemesta kannattaa keskittyä toimivien digitaalisten työskentelymallien kehittämiseen ja tutkimiseen. Kuten Erstadkin (2010, 68-69) toteaa, oppilaiden näkökulmasta koulun ulkopuolella omaksuttujen ja opittujen mobiiliteknologian käyttötapojen tuominen kouluun on luontevaa. Toisaalta koulun on myös mahdollisuus soveltaa erilaisia mobiiliteknologian käyttötapoja tuomalla yhteisöllisiä tiedonrakentamisen ja muokkaamisen prosesseja opetukseen. Tähän myös uusi perusopetuksen opetussuunnitelma 2014 haastaa ja tarjoaa mahdollisuuksia. 


\section{Viitteet}

1 Opetussuunnitelman termi 'monilukutaito' voidaan kääntää englanniksi esimerkiksi multi literacy, multicultural literacy, multimodal literacy tai media literacy, jolloin jokainen käännös johtaa käsitteen erilaisille teoreettisille juurille. Tässä artikkelissa media literacy on lähinnä näkökulmaamme.

\section{Kirjallisuus}

Ahonen, Sirkka (1994). Fenomenografinen tutkimus. Teoksessa: Syrjälä, Leena; Ahonen, Sirkka; Syrjäläinen, Eija \& Saari, Seppo (toim.) Laadullisen tutkimuksen työtapoja. Rauma: Kirjayhtymä Oy, 114-16o.

Arrow, Holly; McGrath, Joseph \& Berdahl, Jennifer. (2000). Small groups as complex systems: Formation, coordination, development and adaptation. Thousand Oaks California: Sage Publications. Zopf, George (toim.) Principles of Self-organization. New York: Pergamon Press, 255-278.

Bass, Kristin \& Bandy, Elizabeth (2010). Digital pathways to learning through collaborative media production. Teoksessa: Tyner, Kathleen (toim.). Media Literacy. New Agendas in Communication. New York: Routledge, 28-50.

Belt, Aino (2013). Kun työrauha horjuu. Kotitalousopettajien käsityksiä työrauhahäiriöistä ja niiden taustatekijöistä. Oulun yliopisto 135.

Berge, Ola (2006). Reuse of Digital Learning Resources in Collaborative Learning Environments. Series of dissertations submitted to the Faculty of Mathematics and Natural Sciences, University of Oslo Nr. 546. https://halshs.archives-ouvertes.fr/hal-00190408/document (luettu 16.6.2015.)

Binkley Marilyn; Erstad, Ola; Herman Joan, Raizen, Senta; Ripley, Martin; Miller-Ricci, May \& Rumble, Mike (2012). Defining twenty-first century skills. Teoksessa: Griffin, Patrick; McGaw, Barry \& Care, Esther (toim.) Assessment and Teaching of 21st Century Skills. New York: Springer, 17-66.

Burn, Andrew. \& Durran, James (2007). Media Literacy in Schools: Practice, Production and Progression. London: Paul Chapman.

Chia, Robert \& MacKay, Brad (2007). Post-processual challenges for the emerging strategy-as-practice perspective: Discovering strategy in the logic of practice. Human Relations, 60, 1, 217-242.

Dewey, John (1957). Koulu ja yhteiskunta. Helsinki: Otava.

Dillenbourg, Pierre (1999). Introduction: What do you mean by "collaborative learning"? Teoksessa: Dillenbourg, Pierre (toim.) Collaborative Learning: Cognitive and Computational Approaches. Pergamon: Oxford, 1-99.

Enkenberg, Jorma; Liljeström, Anu; Pöllänen, Sinikka; Vanninen, Petteri. \& Vartiainen, Henriikka (2014). Design-suuntautuneen oppimisen käsikirja. http://www.slideshare.net/Henriikka/dop21. (luettu 29.6.2014.)

Erstad, O. 2010. Educating the digital generation. Nordic Journal of Digital Literacy, 1, 56-70.

Eskola, Jari \& Suoranta, Juha (2014). Johdatus laadulliseen tutkimukseen. Tampere: Vastapaino.

Gregory, Anne \& Willis, Paul (2013). Strategic Public Relations Leader. Lontoo: Routledge.

Freinet, Celestin (1987). Ihmisten koulu. Moderni ranskalainen koulu - käytännön opas kansan koulun työvälineiden, opetusmenetelmien ja kasvatuksen järjestämiseen. Pedagogiset perusväittämät. Vaasa: Elämänkoulu - Livet skula Ry.

Hakkarainen, Kari (2009). Knowledge practice perspective on technology mediated learning. International Journal of Computer-supported Collaborative Learning 4 (2), 213-231.

Hakkarainen, Kari; Paavola, Sami; Kangas, Kaiju \& Seitamaa-Hakkarainen, Pirita (2013). Socio-cultural perspectives on collaborative learning: Towards collaborative knowledge creation. Teoksessa: Hmelo-Silver, Cindy; Chinn, Clark; Chan, Carol \& O'Donell, Angela. The International Handbook of Collaborative Learning. New York: Routledge, 57-73.

Hartikainen, Mikko \& Harmanen, Minna. 2015. Museot monilukutaidon oppimisen paikkana. Teoksessa: Kinanen, Pauliina (toim.) Museot ja mediakasvatus. Suomen museoliiton julkaisuja 68. http://museoliitto.fi/doc/Museot_ja_mediakasvatus.pdf

Hellström, Martti; Johnson, Peter; Leppilampi, Asko. \& Shalberg, Pasi. 2015. Yhdessä oppiminen, yhteistoiminnallisuuden käytäntö ja periaatteet. Into-kustannus. 
Henderson, Sarah \& Yeow, Jeff (2012). iPad in education: A case study of iPad adoption and use in a primary school. In System Science (HICSS), 2012 45th Hawaii International Conference on, 78-87. IEEE.

Häkkinen, Päivi \& Arvaja, Maarit (1999). Kollaboratiivinen oppiminen teknologiaympäristöissä. Teoksessa: Eteläpelto, Anneli \& Tynjälä Päivi (toim.) Oppiminen ja asiantuntijuus: Koulutuksen ja työelämän näkökulmia WSOY, 206-221.

Ilomäki, Liisa \& Lakkala, Minna (2011). Koulu, digitaalinen teknologia ja toimivat käytännöt. Teoksessa: Kankaanranta, Marja \& Vahtivuori- Hänninen, Sanna (toim.) Opetusteknologia koulun arjessa. Jyväskylän yliopisto, Koulutuksen tutkimuslaitos, 55-76.

Ito, Mizuko., Baumer Sonja, Bittanti Matteo, Boyd Danah, Cody Rachel, ym. (2010). Creative production. Teoksessa: Ito, Mizuko ym. (toim.) Hanging Out, Messing Around, and Geeking Out. Cambridge, Massachusetts: The MIT Press. https://mitpress.mit.edu/sites/default/files/titles/free_ download/9780262013369_Hanging_Out.pdf. (luettu 7.7.2015.)

Jenkings, Henry; Purushotma, Ravi; Weigel, Margaret; Clinton, Katie \& Robinson Alice, J. (2009). Confronting Challenges of Participatory Culture: Media education for the 21st century. MacArthur Foundation reports on digital media and learning. https://mitpress.mit.edu/sites/default/files/ titles/free_download/9780262513623_Confronting_the_Challenges.pdf. (luettu 6.1.2015)

Johnson, David, W. \& Johnson, Roger T. (2009). An educational psychology success story: Social interdependence theory and cooperative learning. Educational Researcher, 38:5, 365.

Johnson, David, W. \& Johnson, Roger,T. (2014). Using technology to revolutionize coperative learning: An opinion. Frontiers in Psychology 2014; 5:1156. http://www.ncbi.nlm.nih.gov/pmc/articles/ PMC4195269/ (luettu 6.1.2016.)

Järvelä, Sanna; Järvenoja, Hanna; Simojoki, Kristiina; Kotkaranta, Saara \& Suominen, Raisa (2011). Miten opettajat ja oppilaat käyttävät tieto- ja viestintäteknologiaa koulun arjessa? Oppimisteoreettinen arviointi. Teoksessa: Kankaanranta, Marja \& Vahtivuori- Hänninen, Sanna (toim.) Opetusteknologia koulun arjessa. Jyväskylän yliopisto, Koulutuksen tutkimuslaitos, 41-54.

Koro-Ljungberg, Mirka (2005). Tietoteoreettinen validiteettitarkastelu laadullisessa tutkimuksessa. Kasvatus 36 (4), 274-284.

Kearney, Matthew, Schuck, Sandra, Burden, Kevin \& Aubusson, Peter (2012). Viewing mobile learning from a peadagogical perspective. Research in Learning Technology, vol 20 (2012). http://www. researchinlearningtechnology.net/index.php/rlt/article/view/14406. (luettu 3.7.2015.)

Kotilainen, Marjo-Riitta (2011). Mobiiliuden mahdollisuuksia oppilaslähtöisen sisällöntuotannon tukemisessa portfoliotyöskentelyssä. Teoksessa: Kankaanranta, Marja \& Vahtivuori- Hänninen, Sanna (toim.) Opetusteknologia koulun arjessa. Jyväskylän yliopisto, Koulutuksen tutkimuslaitos, 141-164.

Kupiainen, Reijo \& Sintonen, Sara (2009). Medialukutaidot, osallisuus, mediakasvatus. Helsinki: Oy Yliopistokustannus, HYY -yhtymä.

Kupiainen, Reijo (2013). Diginatiivit ja käyttäjälähtöinen kulttuuri. Widerscreen 1/2013. http:// widerscreen.fi/numerot/2013-1/diginatiivit/ (luettu 11.7.2015.)

Kurttila, Pasi \& Lang, Markku (2013). Oppimaisema-ajattelua oppimisympäristöihin. Teoksessa: Kokemukset kiertoon - ideoita oppimisympäristöjen kehittämiseen. Oppaat ja käsikirjat 2013:8. Opetushallitus. 98-102.

Lave, Jean \& Wenger, Etienne (1991). Situated Learning. New York: Cambridge University Press.

van Manen, Max (1991). The Tact of Teaching: The Meaning of Pedagogical Thoughtfulness. Albany: State University of New York Press.

Moilanen, Pentti \& Räihä, Pekka (2010). Merkitysrakenteiden tulkinta. Teoksessa: Aaltola, Juhani \& Valli, Raine (toim.) Ikkunoita tutkimusmetodeihin II. Jyväskylä: PS-Kustannus.

Montessori, Maria. (1948). To Educate the Human Potential. Oxford: Clio Press.

Määttä, Kaarina \& Uusiautti, Satu (2012). Pedagoginen auktoriteetti ja pedagoginen rakkaus - Yhdessä vai vastakkain? International Journal of Whole Schooling, 8(1), 21-39.

Naukkarinen, Olli (2011). Tahdikkuus esteettis-eettisenä toimintaperiaatteena. Tiede ja edistys. Helsinki: Tutkijaliitto. - 36 (2011): 4, 315-330.

Norrena, Juho (2013). Tulevaisuuden taitojen opettaminen vaatii muutosta koululta ja opettajilta. Jyväskylän yliopisto. Jyväskylä Studies in Computing numerona 169. Jyväskylä.

OECD. (2014). Pisa 2012. What students know and can do. Student performance in mathematics, reading and Science. http://www.oecd.org/pisa/keyfindings/pisa-2012-results-volume-I.pdf. (luettu 13.7.2015.) 
Opetushallitus. (2011). Tieto- ja viestintätekniikka opetuskäytössä - välineet, vaikuttavuus ja hyödyt. Muistiot 2011:2. http://www.oph.fi/julkaisut/2011/tieto_ja_viestintatekniikka_opetuskaytossa. (luettu 3.7.2015.)

Paavola, Sami, Hakkarainen, Kai \& Seitamaa- Hakkarainen, Pirita (2006). Tutkivan oppimisen periaatteita ja käytäntöjä: "Trialogisen" oppimisen malli. Teoksessa: Järvelä, Sanna, Häkkinen, Päivi \& Lehtinen, Erno (toim.) Oppimisen teoria ja teknologian opetuskäyttö. Helsinki: WSOY, 147-166.

Pennington, Donald (2005). Pienryhmän sosiaalipsykologia. Helsinki. Gaudeamus.

Perusopetuksen opetussuunnitelman perusteet, POPS 2014 (2014). Määräykset ja ohjeet 2014:96. Opetushallitus.

Prensky, Mark (2012). From Digital Natives to Digital Wisdom: Hopefully Essays from 21st Century Learning. Thousands Oaks, California: Sage.

Ryan, Richard M. \& Deci, Edward L. (2000). Intrinsic and estrinsic motivations: Classic definitions and new directions. Contemporary Educational Psychology 25, 54-67.

Salmivalli, Crista (1999). Koulukiusaaminen ryhmäilmiönä. Tampere: Gaudeamus.

Scardamalia, Marlene \& Bereiter, Carl (2008). Pedagogical biases in educational technologies. Educational Technology XLVIII (3), 1-11.

Sahlberg, Pasi \& Sharan, Shlomo (toim.) (2002). Yhteistoiminnallisen oppimisen käsikirja. Helsinki. WSOY. 385-403

Sharples, Mike, Taylor, Josie \& Vavoula, Giasemi (2005). Towards a theory of mobile learning. Proceedings of mLearn 2005, 1(1), 1-9. http://www.mlearn.org/mlearn2005/CD/papers/Sharples-\%20Theory\%20 of\%20Mobile.pdf. (luettu 30.6.2015.)

Selman, Robert L. (1980). The Growth of Interpersonal Understanding. New York: Academic Press.

Sintonen, Sara (2012). Susitunti. Kohti digitaalisia lukutaitoja. Helsinki: Finn Lectura.

Sipilä, Keijo (2013). No Pain, No Gain? Educational Use of ICT in Teaching, Studying and Learning Processes: Teachers' and Students' Views. Acta Universitatis Lapponiensis 269. Rovaniemi: Lapin yliopistokustannus.

Song, Yanjie (2014). "Bring Your Own Device (BYOD)" for seamless science inquiry in a primary school. Computers Q Education 74, 50-60

Schwartz, Katrina (2015). What education technology could look like over the next five years. Mind/Shift How We Will Learn. KQED. http://ww2.kqed.org/mindshift/2015/06/29/what-education-technologycould-look-like-over-the-next-five-years/ (luettu 7.1.2016)

Thompson, Pat \& Hall, Christine (2008). Opportunities missed and/or thwarted? Funds of knowledge meet the English national curriculum. Curriculum Journal, 19, 87-103.

Tanti, Miriam \& Cameron, Leanne (2011). One-to-one computing: Considerations and issues for the higher education sector. Proceedings of ASCILITE - Australian Society for Computers in Learning in Tertiary Education Annual Conference 2011, 1215-1220.

Taylor, Leah \& Parson, Jim (2011). Improving student engagement. Current Issues in Education, 14 (1).

Tuomi, Jouni \& Sarajärvi, Anneli (2002). Laadullinen tutkimus ja sisällönanalyysi. Helsinki: Tammi.

Vahtivuori-Hänninen, Sanna \& Kynäslahti, Heikki (2012). ICT in schools' everyday Life. Teoksessa: Niemi, Hannele, Toom, Auli \& Kallioniemi, Arto (toim.) Miracle of Education: The Principles and Practices of Teaching and Learning in Finnish Schools. Rotterdam: Sense Publishers, 237-248.

Vygotsky, Lev (1978). Mind in Society: The Development of Higher Psychological Processes. Cambridge, MA: Harvard University Press.

Winne, Philip, Hadwin, Allyson \& Gress, Carmen (2010). The learning kit project: Software tools for supporting and researching regulation of collaborative learning. Computers in Human Behavior, 26:5, 787-793.

Zurita, Gustavo \& Nussbaum, Miguel (2006). Computer supported collaborative learning using wirelessly interconnected handheld computers. Computers Q Education 42, 289-314. 